SZYMON SŁOMCZYŃSKI

\title{
"THERE ARE SICK PEOPLE EVERYWHERE - IN CITIES, TOWNS AND VILLAGES”. THE COURSE OF THE SPANISH FLU EPIDEMIC IN POLAND
}

\section{Introduction}

When Wiktor Ruben, the protagonist of Jarosław Iwaszkiewicz's "Panny z Wilka" [The Maids of Wilko], learns from his aunt of the demise of Fela, one of the sisters living on the estate, "the one who would have been the prettiest today", and asks what she died of, he is told "Spanish flu". "Spanish flu" was the name given to the influenza epidemic which was rampant in 1918-1920, causing the early death of many millions of people throughout the world, including young women like Fela. ${ }^{2}$

In recent years, concern over a possible cataclysm, in the form of another influenza pandemic, has once again generated an interest in Spanish flu among many researchers worldwide both in the field of natural and social sciences. The purpose of this paper is to show the probable course of the Spanish flu epidemic in Poland.

As noted by Morens and Fauci, ${ }^{3}$ the epidemiology of Spanish flu remains a mystery. In particular, contrary to all preceding and consecutive pandemics, the Spanish flu epidemic spread throughout the world in at least three subsequent waves, at about nine-month intervals. Not all the preceding pandemics had been of such a recurrent nature, and if they were, the intervals were shorter, as in the $1889-1893^{4}$ pandemic. It is unclear why the Spanish flu pandemic took such a course, or even whether the individual waves were caused by an identical type of virus. ${ }^{5}$

${ }^{1}$ See J. Iwaszkiewicz, "Panny z Wilka", in: id., Opowiadania, Warsaw, 1995, p. 23.

${ }^{2}$ Hereinafter "Spanish flu" is intentionally written without quotation marks.

${ }^{3}$ See D.M. Morens, A. Fauci, "The 1918 Influenza Pandemic: Insights for the 21st Century”, Journal of Infectious Diseases, 195, 2007, pp. 1018-1028.

${ }^{4}$ See ibid., p. 1023.

${ }^{5}$ See ibid., p. 1024. 
The first wave (which occurred in the spring/summer of 1918) was relatively mild with a low mortality rate; however, it covered most continents excepting sub-Saharan Africa ${ }^{6}$ During the second wave (in late summer/autumn of 1918), which started at the French port of Brest, spreading throughout the world at lightning speed, ${ }^{7}$ the number of dead was very high, especially in places which the first wave had bypassed. ${ }^{8}$ The third wave (occurring in the winter of 1919) was characterized by lower mortality due to the population having been partially immunized during the first two waves, while those people most vulnerable to flu had already been killed. In some areas, however, such as Japan, ${ }^{9}$ the morbidity and mortality rates remained extremely high. Some researchers have also isolated a fourth wave of the pandemic (in the winter of 1920), ${ }^{10}$ which mainly, but not only, encompassed geographically isolated or rural areas which had previously had little contact with the virus. This wave-like course of the pandemic occurred in many places around the world, as was already noted in the first pieces of research conducted.

Taking into consideration the scale and importance of the Spanish flu epidemic in Poland, it is rather surprising that Polish historiographers have remained almost silent on the subject. Even the authors of recently published works which concern the fight against contagious diseases in Poland during World War I and immediately after have never mentioned the Spanish flu. ${ }^{11}$ The epidemic was and, of course, still is being mentioned in monographs of a general nature; however, to date, it has not been the topic of a separate publication in Poland nor a topic of research in Polish historiography, even though, as I have shown below, the epidemic did not bypass Poland.

${ }^{6}$ See K.D. Patterson, G.F. Pyle, "The Geography and Mortality of the 1918 Influenza Pandemic", Bulletin of the History of Medicine, 65, 1991, pp. 5-8.

${ }^{7}$ See ibid., pp. 8-13.

${ }^{8}$ See S. Mamelund, "Spanish Influenza Mortality of Ethnic Minorities in Norway 1918-1919", European Journal of Population, 19, 2003, p. 85.

${ }^{9}$ S. Richard et al., "A Comparative Study of the 1918-1920 Influenza Pandemic in Japan, USA and UK. Mortality Impact and Implications for Pandemic Planning", Epidemiology and Infection, 139, 2009, pp. 1062-1072.

${ }^{10}$ See S. Ansart et al., "Mortality Burden of the 1918-1919 Influenza Pandemic in Europe", Influenza and Other Respiratory Viruses, 3, 2009, p. 102.

${ }^{11}$ See, e.g., W. Berner, "Sytuacja epidemiologiczna chorób zakaźnych we Lwowie i Krakowie w okresie I wojny światowej i po jej zakończeniu (do 1922 r.)", Przeglad Epidemiologiczny, 63, 2009, pp. 149-155; E. Więckowska, Walka z ostrymi chorobami zakaźnymi w Polsce w latach 1918-1924, Wrocław, 1999. 


\section{Around the Polish Lands}

Twenty years ago, David Patterson and Gerard Pyle ${ }^{12}$ presented the precise geographical scope of the first three waves of the pandemic both globally and in Europe (Fig. 1), although their determinations contained some inaccuracies, even errors, particularly with regard to Eastern Europe.

The latest results of research conducted on the course of the pandemic in 14 European countries in which accurate demographic statistics are kept, using indirect statistical methods (i.e. comparing the actual and expected mortality rates) were presented by Sevérine Ansart and others in 2009. The latter unequivocally determined that a fourth wave of the pandemic, which occurred in the spring of 1920 should be isolated. ${ }^{13}$ Again, this monograph contributed very little in terms of research on the course of the epidemic on Polish territories, and to the east and south of them. Paradoxically, it seems that far more is known about the spread of Spanish flu in the Pacific Isles than in the heart of Europe. Literature published on the subject to date (excepting Germany) has devoted little space to the very interesting - from the perspective of this study - data from countries which had occupied Polish territory and the surrounding areas before 1918. The political conditions in the area during the pandemic is evidently one of the principal reasons for this: World War I and the local conflicts which erupted soon after the war ended, the process of forming new states as well as the Bolshevik revolution. It is no accident that Patterson and Pyle list Germany, the Austro-Hungarian Empire and Russia as being the countries where the war had the largest impact on hampering the maintenance of demographic statistics. ${ }^{14}$

The number of actual deaths resulting from the Spanish flu pandemic is still under discussion today and the data which can be found in the literature on the subject are only imprecise estimations. Only some regions of the world can provide reliable demographic data which would allow the number of victims of the H1N1 virus in 1918-1920 to be precisely determined. In many countries, these calculations were based on other, indirect, sources such as press releases, reports by the local authorities or articles in medical magazines printed at the time. We owe the first systematic attempts at determining the global num-

${ }^{12}$ See K.D. Patterson, G.F. Pyle, op. cit., p. 4.

${ }_{13}$ They noted a fourth wave of the pandemic in Spain, Denmark, Finland, Germany and Switzerland, see S. Ansart et al., op. cit., p. 102.

${ }^{14}$ See K.D. Patterson, G.F. Pyle, op. cit., p. 13. 


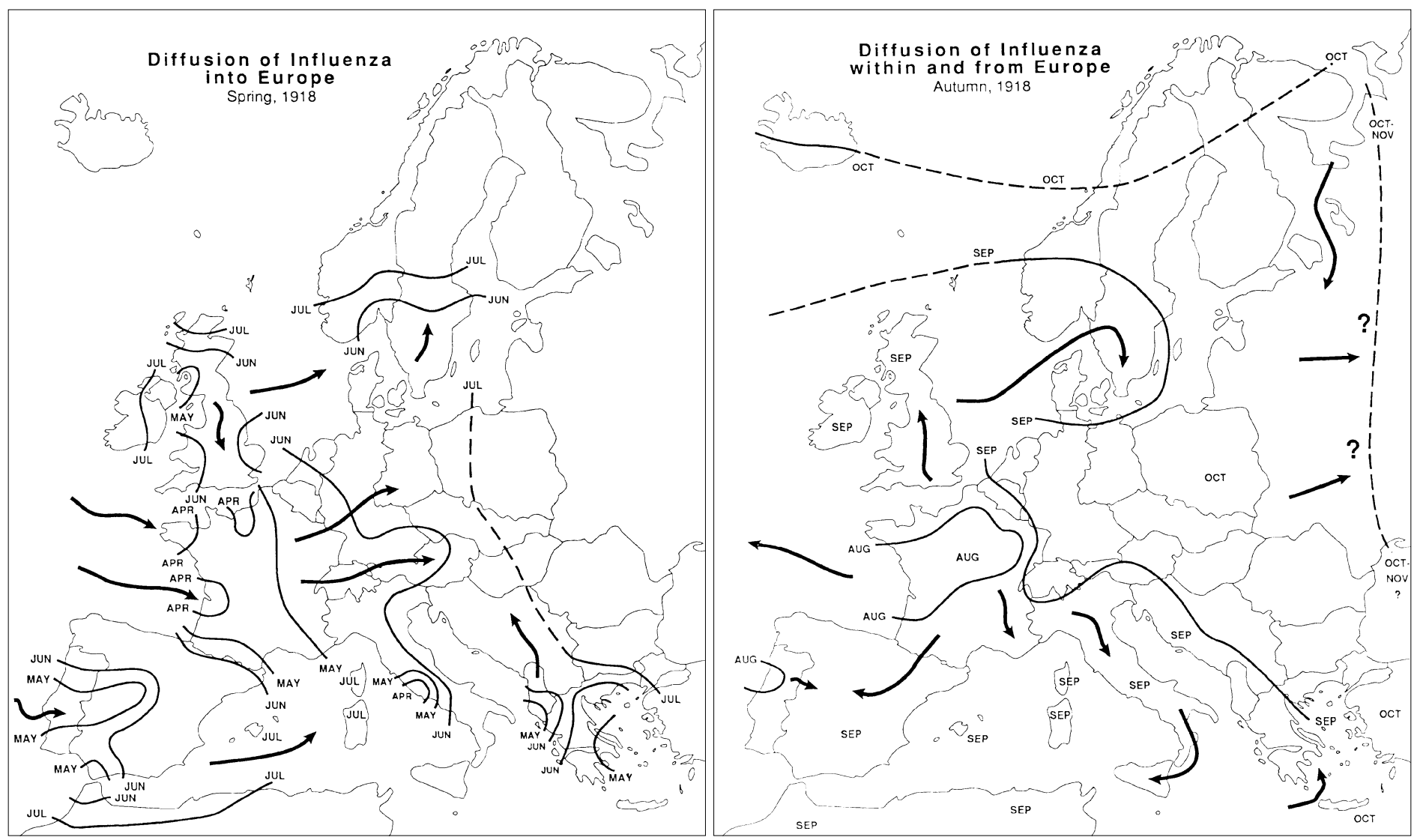

Fig. 1. The first two waves of the Spanish flu epidemic in Europe according to Patterson and Pyle; K.D. Patterson, G.F. Pyle, "The Geography and Mortality of the 1918 Influenza Pandemic", Bulletin of the History of Medicine, 65, 1991, pp. 7, 9. 
ber of Spanish flu mortalities to David Patterson and Gerard Pyle who, in 1991, estimated the upper and lower bounds for the number of victims of the pandemic as between 24.7 million and 39.3 million people, ${ }^{15}$ and subsequently to Niall Johnson and Jürgen Mueller who, in their study dating from 2002, considered these numbers to be grossly underestimated. ${ }^{16}$ From their calculations, it follows that in the two years in which the epidemic raged, the death toll could be put at at least 50 million people, but without eliminating the option of its being as high as 100 million. Recent calculations which were made by a team led by Christopher Murray of Harvard University, based on indirect statistical methods, seem to be the most accurate. ${ }^{17}$ The team compared the actual number of deaths in 1918-1920 with the expected number obtained on the basis of data for 1915-1917 and 1921-1923, but only for countries whose demographic statistics could be considered at least $80 \%$ complete. These calculations tended to be similar to those proposed by Johnson and Mueller.

Irrespective of the detailed determinations concerning the number of deaths, there is no doubt that the number of sudden deaths occurring throughout those two years, above all in the autumn months of 1918, was very high indeed. Less people died in both World Wars which lasted for a total of ten years! Also, fewer people have died of AIDS in the past thirty years. The Spanish flu epidemic was, therefore, by far one of the largest catastrophes in the history of mankind.

Research to establish the details of the 1918-1920 flu epidemic has now been conducted for many years, however usually on a local level. In the context of this article, the results of research carried out in Europe, and specifically Central Europe, are evidently the most interesting. By carrying out a detailed analysis of the number of victims in Europe, again based on indirect statistical methods, as in Murray's work (i.e. comparing the actual total deaths in 1918-1922 with the expected number obtained on the basis of data for 1906-1917) has enabled French researchers to estimate the numbers very precisely in 14 European countries inhabited by three-quarters of the continent's

${ }^{15}$ Ibid.

${ }^{16}$ N.P.A.S. Johnson, J. Mueller, "Updating the Accounts. Global Mortality of the 1918-1920 "Spanish" Influenza Pandemic", Bulletin of the History of Medicine, 76, 2002, pp. 105-115.

${ }^{17}$ C. Murray et al., "Estimation of Potential Global Pandemic Influenza Mortality on the Basis of Vital Registry Data from the 1918-1920 Pandemic: a Quantitative Analysis", Lancet, 368, 2007, pp. 2211-2218. 
population and to extrapolate it to the whole of Europe. ${ }^{18}$ The number of deaths in Europe caused by the Spanish flu pandemic was estimated at 1,980,950 in the 14 countries covered by the research, compared with 2,300,000 in Patterson's and Pyle's, and Johnson's and Mueller's studies (estimate for the whole of Europe) and 2,005,569 (for 13 countries) in Murray et al.'s study. ${ }^{19}$

In respect of countries whose lands became part of the Republic of Poland after 1918, the above-named authors provided some very specific data (for Russia: 450,000 - Patterson and Pyle; ${ }^{20}$ for Germany: 250,000-300,000 - Patterson and Pyle, 225,330, and an additional 236,662 for Prussia, Johnson and Mueller, 426,574 - Ansart et al.; for Austria and Hungary: ca. 125,000 in total - Patterson and Pyle, but it is not always clear whether they were referring to the countries within their pre-1918 boundaries or later. Moreover, as far as Russia and Hungary were concerned, the researchers themselves admitted they were referring to a very approximate estimate. Murray et al. assessed the additional number of deaths caused by Spanish flu per 100 inhabitants at 1.61 for Austria and 0.76 for Germany, without stating precisely which territories they were referring to.

The extensive report on the course of the global flu pandemic (which came to Great Britain in 1918 and 1919) published in London in 1920 provides further information which, however, only gives fragmentary data for Central Europe. ${ }^{21}$ For example, it mentions three waves of the pandemic in Vienna (the first half of June 1918, September and October 1918, early 1919), the closing of schools, the illness of the emperor Charles and his family, the high morbidity in Prague and 3,368 flu victims in Budapest at the end of 1918, with morbidity and mortality peaking in the Hungarian capital in mid November. The data for Soviet Russia is less accurate. The authors noted very high morbidity in Odessa in mid October (where the Polish composer, Karol Szymanowski, also suffered from a slight bout of Spanish flu), ${ }^{22}$ mentioning that they called the disease "Chinese flu", thereby concluding that due

${ }^{18}$ See S. Ansart et al., op. cit.

${ }^{19}$ See ibid., p. 102.

${ }^{20}$ Patterson and Pyle called the attempt at estimating the number of fatalities in Russia "a shot in the dark". See K.D. Patterson, G.F. Pyle, op. cit., p. 16.

${ }^{21}$ See Reports on Public Health and Medical Subjects, no. 4 Report on the Pandemic of Influenza, 1918-1919, London, 1920, pp. 261-274.

${ }^{22}$ In October 1918, in his letters to Maryanna Dawidowa and Stefana Spiess, Szymanowski wrote of his experience with the "damned Spanish flu". See Karol Szymanowski. Korespondencja. Petna edycja zachowanych listów od i do kompozytora, vol. 1: 1903-1919, ed. by T. Chylińska, Warsaw, 1982, pp. 556, 558. 
to their extreme backwardness and poor sanitary conditions, the percentage of deaths in Russia must have been particularly high. With regards to Germany, the archival sources mention a theory which suggested that, contrary to popular opinion, the pandemic came to the Reich from the east, first breaking out on the Eastern Front, although they did consider this theory controversial. According to the authors of the British report, the epidemic came in three waves, in July and October 1918 and February 1919, i.e. a month after breaking out in Austria. The peak of morbidity everywhere was late October, with Wrocław being the city that suffered most.

Invaluable information on the course of the Spanish flu epidemic in Russia can be found in a recently published series of articles by the Russian epidemiologist, Mikhail W. Supotnitskij. ${ }^{23}$ Both these articles as well as studies by his fellow countrymen dating from 1919, which he quotes therein, were written in Russian which probably explains why they are never referred to in English language literature on the subject, but it is a reason why it would be worth discussing them in more depth. According to the author, the first wave of the pandemic in Russia was rather mild and passed largely unnoticed. In August and September 1918, information on the new disease began filtering in to the Ludowy Komisariat Zdrowia (People's Health Committee) from all parts of the country, which was engulfed in civil war and revolutionary chaos. In Russia, the flu first appeared on 13 August in Mstsislaw, spreading in the same month to Ryazan, Kursk, Smolensk, Petersburg and Perm. In September the epidemic broke out in Vitebsk, Volodymyr, Viatka, Voronezh, Kaluga, Mogilev, Novgorod, Penza, Pskov and Tver, later appearing in Kazan, Moscow, Nizhny Novgorod and Saratov in October, and then the Crimea at the end of the month. This shows that the epidemic spread from the south-west to the north-east of Russia. Supotnickij also added - without quoting any sources - that there were 700,000 people sick in Kiev at that time, which means that almost all the inhabitants of the Ukraine's capital city had succumbed to the disease, while mortality was at $1.5 \% .{ }^{24}$

${ }^{23}$ M.W. Supotnickij, "Pandemija »Ispanki« 1918-1920 gg. w kontekste drugix grippoznyx pandemij i "ptič 'ego grippa«", Medicinskaja kartoteka, 2006, no. 11, pp. 31-34; no. 12 , pp. 15-25 and 28-30; 2007, no. 1, pp. 16-22. The articles were also published on Supotnickij's home page: see http://www.supotnitskiy.ru/stat/stat51.htm\#gl2 (access: 31 May 2012).

${ }^{24}$ In Kiev, which was then ruled by Hetman Pavlo Skoropadskij, the Polish writer and author of memoirs Maria Dunin-Kozicka, fell sick with the flu; describing her uncomfortable journey by train from Monasterzyska to Kiev in early October 1918, 
Supotnickij gives the exact number of sick people in particular provinces quoting Pieuranskij, ${ }^{25}$ who indicated that morbidity was highest in the Volodymir, Pskov and Smolensk provinces and lowest in the Moscow province. ${ }^{26} \mathrm{He}$ also emphasized that in Russia, Spanish fever was only a minor episode against the backdrop of other catastrophic epidemics which ravaged a country torn by wars and revolutionary terror in the early years after the war, claiming hundreds of thousands of victims. These included: the plague (Astrakhan 1918, Far East 1921-1922); cholera (Central Asia, Caucasus and Siberia, 1921); typhus (the whole territory of Russia, 1918-1922), and malaria (the whole territory of Soviet Russia, 1921).

The early appearance of the second wave of the epidemic in Russia is rather surprising given the situation in other European countries as it seems to contrast starkly with the descriptions of this phase of the pandemic found in global literature. In the light of data from this source, it would seem that Patterson and Pyle's suggestions that the second wave of the epidemic did not arrive in Russia before October or November (see Fig. 1) are incorrect. Also given the status of current research, it is unclear how the second wave of Spanish flu could have reached Russia as early as in August if it was only present in France at that time.

We cannot, therefore, dismiss the possibility that the second wave of the epidemic entered Poland simultaneously from three directions (in August from Russia, ${ }^{27}$ in September from Austro-Hungary and in October from Germany), and that the three waves of Spanish flu which came into Poland from the partitioning states met at the River Vistula. ${ }^{28}$

she mentioned that "the journey in the company of robbers and thieves, in a dirty and not very airy carriage (...) left its mark in the form of the unbearable Spanish flu which troubled me in Kiev for a long time." Quoted after: M. Dunin-Kozicka, Burza od Wschodu, Warsaw, 1990, p. 110.

${ }^{25}$ See A. Pieruanskij, "Ob »ispanskoj« bolezni”, Izwiestija narodnogo komissariata zdrawooxranenija, 1919, nos. 7-8, pp. 32-33. Quoted after: M.W. Supotnickij, op. cit.

${ }^{26}$ George Kohn indicated, quoting the book by V.M. Zhdanov; V.D. Solov and F.G. Epshtein, translated from the Russian in the 1950s: The Study of Influenza. A Translation of Ucheniye o Grippe (published in Moscow in 1958), that mortality in the largest Russian cities - Moscow and St. Petersburg - was rather low; however, we do not know how reliable the data is. See G.C. Kohn, Encyclopedia of Plague and Pestilence: from Ancient Times to the Present, New York, 2008, p. 313.

${ }^{27}$ Spanish flu was also known in Poland as "the Bolshevik disease", which unequivocally indicates the direction from which the epidemic spread. See R. Collier, The Plague of the Spanish Lady. The Influenza Pandemic of 1918-1919, London, 1996, p. 82.

${ }^{28}$ In his memoirs, Ryszard Teofil Michalczyk wrote: "After disarming the Germans I found myself with my group of students in the Academic Legion (later 36th Infantry 


\section{Time of plague}

The Polish press, like the global press, gave information about the epidemic raging in faraway Spain as early as in late May/early June of 1918. ${ }^{29}$ Although the nature of the "very rapidly" spreading epidemic had not yet been discovered, it was claimed that one-third of the Spanish population had succumbed to the disease however stating that "the sickness is not serious" 30 is over in a few days, after which the patients "recover completely". ${ }^{31}$

Over the following weeks, the pandemic gradually spread throughout Europe, reaching the German Reich at the end of June. By reading the newspapers which quoted the opinions of German doctors it could be learned that "the disease seems to be influenza" but "there is no cause for concern as it is taking a normal course". ${ }^{32}$ As it later transpired, this was the first, far milder than the next, wave of one of the deadliest epidemics in the history of mankind and but a prelude to its most deadly phase. It very quickly stopped being just a piece of faraway news for Polish readers, instead becoming part of their everyday lives.

In the course of my research to date, I have tried to determine as precisely as possible when exactly the Spanish flu epidemic broke out in Poland. The hypothesis that the epidemic in Poland, as in the rest of Europe, came in several distinctive waves seems natural, and - as I shall prove below - this is the course of events reflected in the source documents.

In the first days of July 1918, flu morbidity in Pomerania and Wielkopolska hit epidemic proportions. In Jarocin one-fifth of the population was sick and a disturbingly high morbidity rate was also noted in Ostrów Wielkopolski, Gdańsk and Torun. ${ }^{33}$ The first descriptions of influenza began appearing in the daily papers; the illness was believed to be the same one that had raged in Europe in the 1880s, and the symptoms were listed. From the very outset, the extreme suddenness with which it attacked humans was strongly emphasized:

\footnotetext{
Regiment). With our company we departed for Lwów. At that time, Poland was engulfed by flu called the Spanish flu or the Ukrainian flu, because the wave coming from the West and from the Ukraine met in the territory of Poland". Quoted after: R.T. Michalczyk, Z Włocławka do Wrocławia, Wrocław, 1976, p. 28.

${ }^{29}$ See Czas, 3 June 1918.

${ }^{30}$ See Dziennik Poznański, 29 May 1918.

${ }^{31}$ See Dziennik Wileński, 2 June 1918.

${ }^{32}$ Kurier Poznański, 2 July 1918.

${ }^{33}$ See Kurier Poznański, 3 July 1918 and 5 July 1918.
} 
"a person may feel well in the morning but develops a high fever by the afternoon". ${ }^{34}$ It was also stated that the best way of counteracting Spanish flu symptoms was to immediately go to bed, as any hesitation to do so could lead to serious complications for the sick person, particularly with regard to the respiratory system. It was also emphasized (probably so as to prevent panic) that "nobody has yet died of the illness" but "everybody should be aware they could be hit by the Spanish flu epidemic some fine morning or afternoon". ${ }^{35}$

The reports on the summer wave of Spanish flu by journalists from the local magazine "Czas", in Kraków, describe rather well the extraordinary speed at which the influenza spread among the local population. On 14 July they reported that "Although Spanish flu has come to Kraków, only a few sporadic cases have been noted, and with very mild symptoms", ${ }^{36}$ but by 17 July so many employees of just one enterprise - the Krakowska Spółka Tramwajowa company - had fallen ill that the directors were forced to significantly reduce the number of tram runs. ${ }^{37}$ They also reported that several rowers were unable to participate in the rowing competition held on the River Vistula alongside the Wawel castle because they had caught the flu. ${ }^{38}$

The Spanish flu epidemic raged in Warsaw more or less concurrently; the Prime Minister of the Regency Council, Jan Steczkowski, fell ill, a fact that was widely commented on in the daily press. ${ }^{39} \mathrm{In}$ mid-July the flu epidemic also "significantly impacted" the inhabitants of Poznan and although its course was usually mild, some patients died of pneumonia ${ }^{40}$ which was the most frequent as well as dangerous complication. A careful study of the obituaries published in "Kurier Poznański" enables us to name, with a high degree of certainty, some of the first victims of the first wave of the Spanish flu in Poland: 13-year-old Leokadia Hain died as early as on 10 July, and her older sister, Stanisława, a day later. Within two days, after a similarly short bout of illness, sixteen-year-old Leon Kasprzak and his eighteen-year-old sister Czesława also died. ${ }^{41}$

It is, therefore, evident that the first summer wave of the Spanish flu epidemic certainly did not bypass Poland. Furthermore, as in other

\footnotetext{
${ }^{34}$ Kurier Poznański, 5 July 1918.

${ }^{35}$ See Kurier Poznański, 3 July 1918.

${ }^{36}$ Czas, 14 July 1918.

${ }^{37}$ See Czas, 18 July 1918.

${ }^{38}$ Czas, 15 July 1918.

${ }^{39}$ See Czas, 20 July 1918; Kurier Poznański, 20 July 1918.

${ }^{40}$ See Kurier Poznański, 16 July 1918.

${ }^{41}$ See Dziennik Poznański, 17 July 1918.
} 
European regions, it seems to have been characterized by extremely high morbidity and relatively low mortality. We can assume that the first phase of the epidemic was extinguished as suddenly as it emerged, fully withdrawing by the end of July - in August the press makes no mention of flu. It is rather extraordinary that Szczęsny Bronowski, the author of the only study on the Spanish flu in Poland published in 1922, did not mention this first wave of the epidemic. When writing about the summer wave of the epidemic which raged throughout Europe, he noted that "in May 1918 Spain was alarmed by a mysterious disease. By June the disease had spread to France and the whole of Germany", but he totally omitted a description of the summer epidemic in Poland, immediately passing to the autumn wave: "In Lwów and in Kraków the flu appeared towards mid-September, while in October it raged, in the form of an epidemic, throughout the whole Dabrowskie Basin. In Warsaw isolated cases of flu were noted in September and by October the Spanish flu epidemic was widely acknowledged". ${ }^{2}$

This oversight may be explained by the fact that since it was the second bout of the epidemic which proved so fatal for such a large number of people, only then did it begin to be perceived as an important social problem and an enormous challenge both for the administration and medical practice. Although the Spanish flu had been closely observed in the first wave of the epidemic, it had been treated more like an initially unknown illness that came from abroad, but which turned out to be flu (as was correctly diagnosed by some doctors, such as the celebrated Lwów clinicist, Roman Rencki, as early as in July). ${ }^{43}$ The Spanish flu epidemic of July did not arouse the interest of the sanitary services and, based on the archival data collected, it is hard to assume people were more afraid of it than for example dysentery, typhus or cholera, which were (quite rightly) considered extremely dangerous diseases. That was soon to change.

The Spanish flu returned to the territory of Poland in mid September, a fact people were informed about retrospectively, because a huge increase in Journalist's interest in the influenza epidemic can only be noted in late September, early October. In the ensuing weeks, the press described the second bout of the Spanish flu epidemic many times over. The press releases largely relate to various aspects of the epidemic outside Poland, mainly in European capital cities, although many also referred to its manifestations in the territory which was soon to become

${ }^{42}$ S. Bronowski, Epidemia grypy w latach 1918-1920 (jej istota, objawy, zapobieganie i leczenie): odczyt kliniczny, Warsaw, 1922, p. 4.

${ }^{43}$ See R. Rencki, "O obrazie klinicznym grypy hiszpańskiej”, Przeglad Lekarski, 42, 1918, p. 284. 
the Second Polish Republic and as they vary so much, it is possible to draw a quite accurate picture of its course in Poland. Due to the specific nature of the source documentation analyzed, i.e. press releases published by only a few newspapers (albeit from different parts of the country) it is obviously not possible to create a reliable picture of the morbidity and mortality resulting from the Spanish flu epidemic. However, by reading the press, the period when the second wave of the epidemic passed through Polish territory can be defined rather precisely.

The Miejski Urząd Zdrowia (City Healthcare Office) in Kraków gave information about "frequent cases of the Spanish sickness" in the press as early as on 20 September, but they only noted one fatal case. ${ }^{44}$ Several days later, in the nearby city of Tarnów, the epidemic caused so many people to become ill that the local healthcare office decided to close all schools. ${ }^{45}$ Due to very few pupils attending classes and the threat of the situation deteriorating even further, classes were also suspended in Dębica (where the director of the local State Secondary School, Józef Szydłowski ${ }^{46}$ unexpectedly fell ill with the flu) as well as in Lublin. ${ }^{47}$ When four-year-old Edward Włach suddenly died of Spanish flu in Lwów, the epidemic was described as "dangerous". ${ }^{48}$ It assumed "formidable proportions" in the schools in Lwów where "a great number of children" fell ill and many classes were depleted due to the epidemic. ${ }^{49}$ In Rzeszów, the course of the Spanish flu epidemic was "often very serious, sometimes even fatal". ${ }^{50}$ In the second half of September more than one hundred people in Kraków died of the flu, although the mortality rate among the sick was estimated at a City Sanitary Council meeting at no more than $1 \% .{ }^{51}$ In the early days of October, the city's chief doctor, Tomasz Janiszewski, stated that over 20,000 of Kraków's inhabitants had already had Spanish flu. ${ }^{52}$

In early October, the epidemic in Wielkopolska intensified considerably. The press warned that "the current symptoms are far worse than before, as whole families suddenly succumb to Spanish flu and are

${ }^{44}$ See Czas, 20 September 1918.

${ }^{45}$ See Czas, 26 September 1918.

${ }^{46}$ See Sprawozdanie Dyrekcji Gimnazjum Państwowego w Dębicy za rok szkolny 1918/1919, Dębica, 1919, p. 7.

${ }^{47}$ See Sprawozdanie Dyrekcji Państwowego Seminarium Nauczycielskiego Żeńskiego w Lublinie za rok szkolny 1918/1919, Lublin, 1919, p. 12.

${ }^{48}$ See Kurier Lwowski, 27 September 1918.

${ }^{49}$ See Czas, 27 September 1918.

${ }^{50}$ Głos Rzeszowski, 29 September 1918.

${ }^{51}$ See Czas, 28 September 1918.

${ }^{52}$ See Nowa Reforma, 4 October 1918. 
unable to care for one another". ${ }^{53}$ The flu also raged in Gdańsk, where on 8 October the mayor of the city, Henryk Schultz, a man in the prime of his life, died leaving behind his wife and son, who had been born the day before. ${ }^{54}$ In October of that year, many families were to experience similar tragedies as Schultz's wife. Both the press and medical magazines noted that it was often very young people who were the victims of the epidemic. The age structure of the deaths caused by Spanish flu was characteristic of its course throughout the world, Poland being no exception. Here the Spanish flu "killed mainly young people", ${ }_{55}$ and even though the war had been going on for four years, it was difficult for society to come to terms with the extremely high number of deaths, as can be seen from the press releases. For example, when a thirty-one year old pianist, Eugenia Kmieć née Reszka, died of the flu in Rzeszów on 16 October, the local press emphasized "the strong impression the young woman's sudden and unexpected death had made". ${ }^{56}$

October and November 1918 were the worst months in which the number of cases of Spanish flu in Poland reached its peak. Descriptions dating from that time indicate that the epidemic was of such horrendous proportions that it was beginning to hamper people's day to day lives. In Lwów, in mid October, there were even problems when trying to bury the dead; the press stated that "the municipal funeral house is unable to provide enough coffins and personnel to conduct the burials. There are times when the deceased cannot be buried because of these shortages, even three days after their death". ${ }^{57}$

The epidemic also caused considerable problems among press circles. On 24 October the editorial offices of all the major papers in Kraków issued a joint statement in which they apologized to readers for any delays they experience in receiving their subscribed papers as "a large portion of the paper boys" had fallen ill with Spanish flu. ${ }^{58}$ For these same reasons, the size of "Dziennik Bydgoski" ${ }^{59}$ was significantly reduced at the end of October.

${ }^{53}$ Kurier Poznański, 9 October 1918.

${ }^{54}$ See Kurier Poznański, 12 October 1918.

${ }^{55}$ Kurier Lwowski, 21 October 1918.

${ }^{56}$ Gtos Rzeszowski, 20 October 1918.

${ }^{57}$ Kurier Lwowski, 21 October 1918.

${ }^{58}$ See Czas, 24 October 1918. The declaration was signed by the administrations of Czas, Nowa Reforma, Głos Narodu, Goniec, Ilustrowany Kurier Codzienny.

59 "Spanish flu is spreading throughout our city. Due to a large number of our personnel falling sick, we are unable to complete editorial work. We ask for your understanding", Dziennik Bydgoski, October 1918, quoted after: K. Błażejewski, "Hiszpańska zaraza w mieście naszem", Nowości, 22 May 2009. 
Although at this stage of the research, the rate of morbidity cannot be accurately determined, it must have been very high since the information that repeatedly appeared claiming that "there is not a house in which someone has not been ill with the Spanish flu"60 is not an exaggeration. This is confirmed by press releases from other parts of Poland. A note in "Kurier Warszawski" claimed that in the Kingdom of Poland "people in the cities, towns and villages are sick with Spanish flu", as well as mentioning the difference between the light summer bout and serious autumn bout of the epidemic. ${ }^{61}$ In Kielce it was claimed that one quarter of the inhabitants were sick with Spanish flu at the same time, ${ }^{62}$ and in Ostrów, "Kurier Poznański" stated that in the third week of October, "[Spanish flu - Sz.S.] is spreading more and more. There is not a home in which several people are not sick. Deaths are multiplying, especially among poorer people. In the previous week every day 3 or 4 people killed by the epidemic were buried near the Catholic Church". ${ }^{3}$

Although the number of fatalities caused by the second wave of the epidemic in Poland cannot be determined in a statistically reasonable manner based on the source data I have collected, the numerical data for particular locations which I have quoted below illustrate the possible scenarios for its development. Less hypothetical data on the number of deaths caused by the flu epidemic could only be provided were a statistically material number of parish records to be reviewed since no statistics relating to the morbidity or mortality resulting from the Spanish flu were maintained in Poland at that time. However, despite the difficulties in determining the actual quantifiable size of the epidemic throughout the country, I believe it is possible to look at it on a smaller scale, and also worthwhile.

There is official data on the mortality resulting from the epidemic in particular weeks for Kraków, Lwów and Poznań because they were published in the press. The Kraków data seems to be the most complete and reliable. In the first half of September there were only three flu victims, but from 15 to 28 September it killed 94 people. In the three following weeks the number of people dying from flu was on a similar level: 98 people from 29 September to 5 October, 87 people from 6 to 12 October and 88 people from 13 to 19 October. After that the

\footnotetext{
${ }^{60}$ Czas, 19 October 1918.

61 "In the summer people had mild symptoms, now they are more serious", Kurier Warszawski, October 1918, quoted after: Czas, 28 October 1918.

${ }^{62}$ See ibid.

${ }^{63}$ Kurier Poznański, 23 October 1918.
} 
number of deaths fell, so it can be deduced its intensity also dropped. The epidemic claimed 66 victims from 20 to 26 October and 49 from 27 October to 2 November. Later, data was no longer being published. At first only the deaths of people who had been diagnosed with the flu were noted in Lwów, omitting those who died as a result of complications, mainly pneumonia. The incomplete data from Lwów, Kraków and Poznań shown below (Fig. 2) does, however, enable us to better understand the course of the most violent wave of the influenza epidemic and, despite the long distances between the various locations, to establish that it reached its peak in mid October. ${ }^{64}$

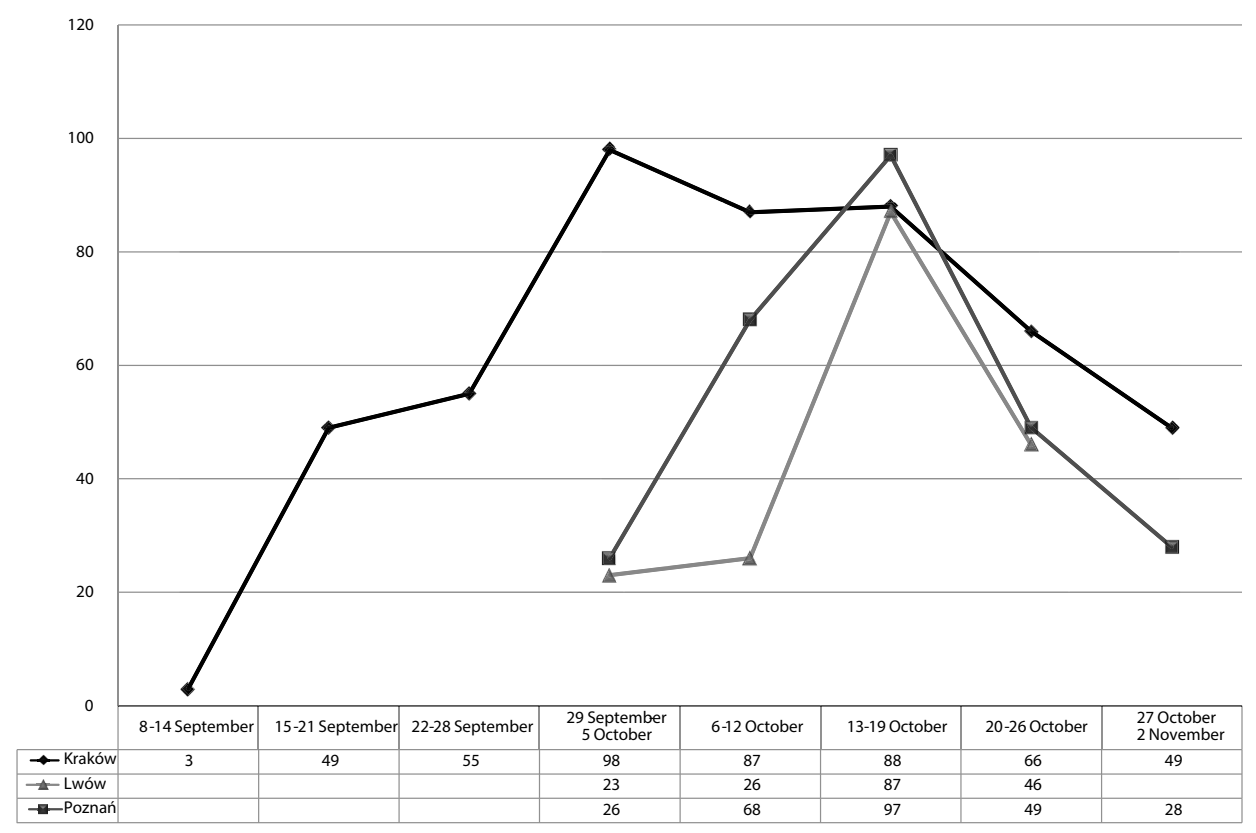

Fig. 2. Victims of Spanish flu in Kraków, Poznań and Lwów in the autumn of 1918 (2nd wave); based on information in: Czas, Dziennik Poznański, Gazeta Lwowska, Kurier Lwowski, Kurier Poznański, autumn 1918.

Data developed on the basis of parish records relating to Spanish flu mortality in four selected parishes in the Tarnów district (Figs. 3 and 4) enables us to look at the period of the epidemic from a wider perspective.

${ }^{64}$ In December an epidemic of typhus erupted in Kraków; the municipal authorities concentrated on that epidemic. In some homes both illnesses occurred simultaneously - the Polish writer, Stefan Żeromski, who had spent winter 1918/9 in Kraków, fell ill with the flu, and his daughter Monika with typhus. See J. Bieniarzówna, J.M. Małecki, J. Mitkowski, Dzieje Krakowa, vol. 4: Kraków w latach 1918-1939, Kraków, 1997, p. 14; J. Paszek, Żeromski, Wrocław, 2001, p. 156. 


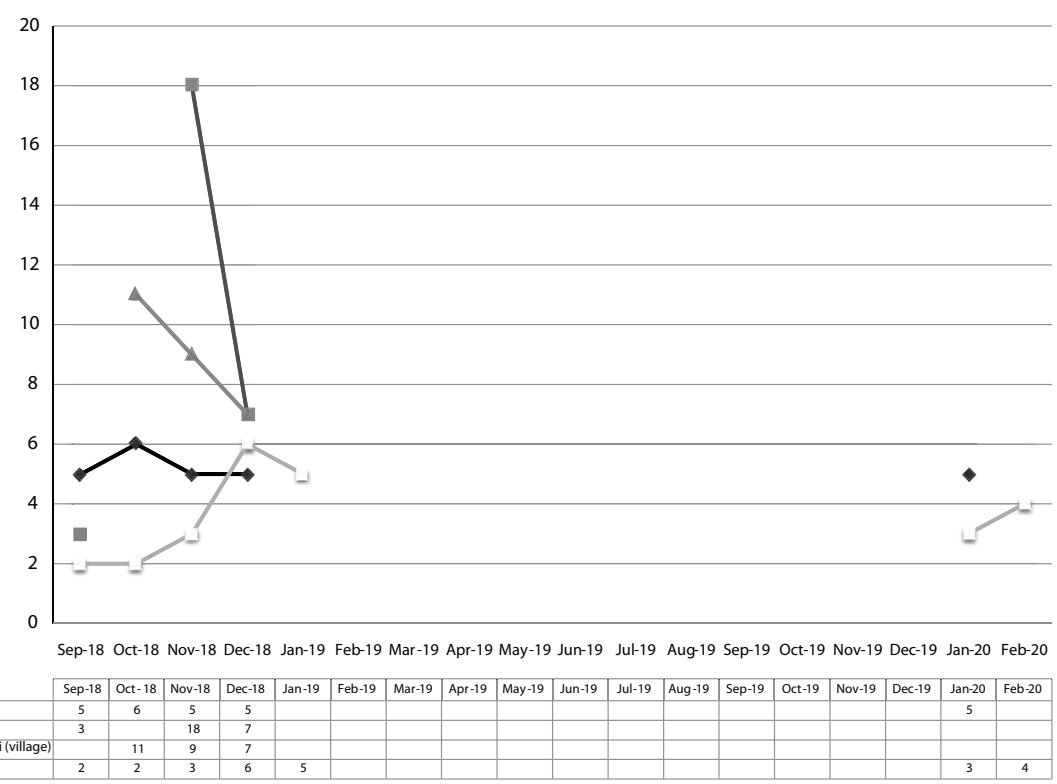

Fig. 3. Deaths caused by the Spanish flu in selected parishes and particular villages in the Tarnów district, based on the records of deaths in Roman Catholic parishes in Ciężkowice, Jastrzębia, Rzepiennik Strzyżewski and Zborowice.

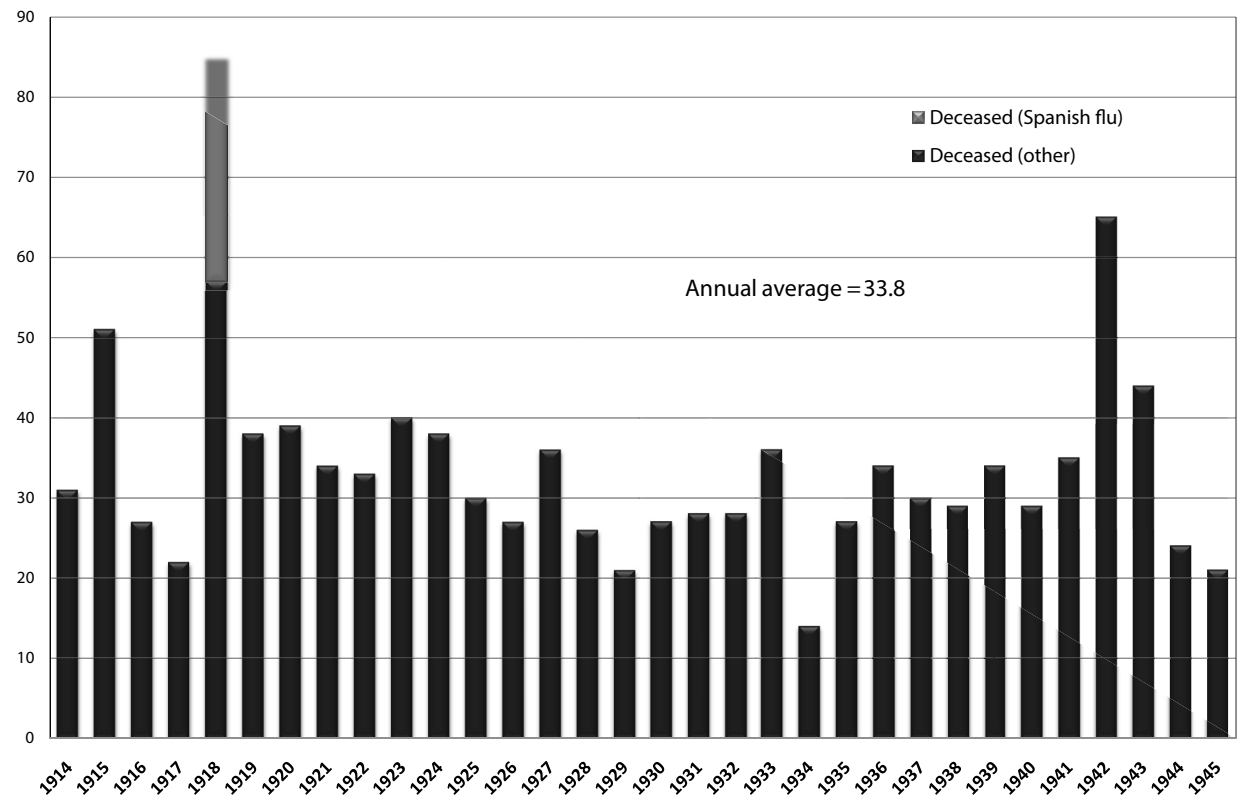

Fig 4. Deaths in Jastrzębia, a village in the Tarnów district, in 1914-1945; based on the records of deaths in Roman Catholic parish in Jastrzębia. 
Such a small sample does not allow us to exclude the hypothesis that Spanish flu may also have taken its toll on people in the territory of Poland in other periods, such as the spring of 1919. The schedule presented (Fig. 3) confirms the existence of at least two waves of the epidemic: late autumn/early winter of 1918, which may have lasted until January, and the winter wave in 1920. Moreover, data collected from parish records shows that, similarly to the village of Jastrzębia (Fig. 4), the epidemic may have grown to proportions which had a significant impact on the annual mortality rate in a given location.

\section{Conclusion}

Below I have attempted to summarize the picture of the Spanish flu pandemic on the territory of Poland: it did not come to Poland before late June/early July of 1918. The first wave of the epidemic was characterized by high morbidity and a relatively low mortality rate, reaching its peak in mid July, following which it gradually phased out over the next few weeks.

The second, most serious wave of the epidemic, lasted from mid September 1918 to mid February 1919, peaking in October and November. It most probably reached Polish territory simultaneously from the West and East, and spread very quickly, reaching pandemic proportions throughout Poland in late September/early October. Morbidity during the second wave was extremely high, it is even possible that most inhabitants fell ill with Spanish flu. It is difficult to accurately determine the mortality rate based on the data collected.

The third wave of Spanish flu, noted in many European countries in the spring of 1919, bypassed the German Reich, the same probably happening in Poland. The source data collected shows that the epidemic had subsided by late February only to reappear the following year.

The subsequent wave, by some researchers called "the fourth wave of Spanish flu", ${ }^{65}$ would therefore have been the third wave in Poland. It appeared in the winter of 1920 and the course of the epidemic seemed less severe than during the second wave, but more severe than the first wave, as it again led to deaths. It also caused concerns among the central authorities, the Ministry of Health even issued a decree requiring that, in compliance with the law, all cases of flu with pneumonia be reported as a contagious disease. ${ }^{66}$

\footnotetext{
${ }^{65}$ See S. Ansart et al., op. cit., pp. 99-106.

${ }^{66}$ See Dziennik Ustaw Rzeczypospolitej Polskiej, item 19, no. 103, 1920.
} 
It should be remembered that the most serious, second wave of the epidemic, was concurrent with the huge supply problems related to the depletion of the economic systems of the partitioning countries caused by a long war, the often insufficient level of medical care, the co-existence of many serious epidemics (in particular dysentery and typhus), as well as the backwardness of certain areas of Poland vis-à-vis Western European countries. These factors could have resulted in the relatively high mortality rate in Poland during the epidemic because, as has been shown globally in much of the foreign research, this is usually strongly related to a given economy's level of wealth. However, based on the data collected, it is not possible to determine, or even estimate, the number of people who died in Poland during the three waves of the epidemic.

The Spanish flu epidemic of 1918-1920 is often called "the forgotten epidemic". As Patricia Marsh rightly pointed out in her article about the coverage given by the Irish press to the course of the Spanish flu epidemic, the characteristic amnesia about the epidemic, which claimed millions of human lives worldwide, derives from the fact that it was concurrent with the ending of World War I which in itself resulted in many transformations of a social, political and cultural nature. ${ }^{67}$ It is very probable that the political changes which were then taking place in Ireland were the main reason why the great flu epidemic was nearly forgotten. This was also accompanied by insufficient mention of the flu epidemic being made in source documents because Irish journalists at the time were far more interested in current political events. It is easy to see that the situation was very similar to the one in Poland. The myriad events of such significance to Polish political history, including the country's revival - as the Second Polish Republic - following years of being partitioned, undoubtedly resulted in the Spanish flu epidemic - which caused so much suffering for so many being omitted both in the press and journals, as well as almost totally in studies by historians.

The only Polish war cemetery in North America, located in Niagara-on-the-Lake, Ontario, Canada, was for soldiers of General Józef Haller's Blue Army who died of Spanish flu, a fact which must arouse the curiosity of people interested in Polish history from the political and military perspective. During the influenza epidemic in autumn 1918 several dozen of the volunteers in Haller's army, who were being

${ }^{67}$ See P. Marsh, "»Mysterious Malady Spreading“. Press coverage of the 1918-1919 influenza in Ireland", Quest 4, 2008, p. 176. 


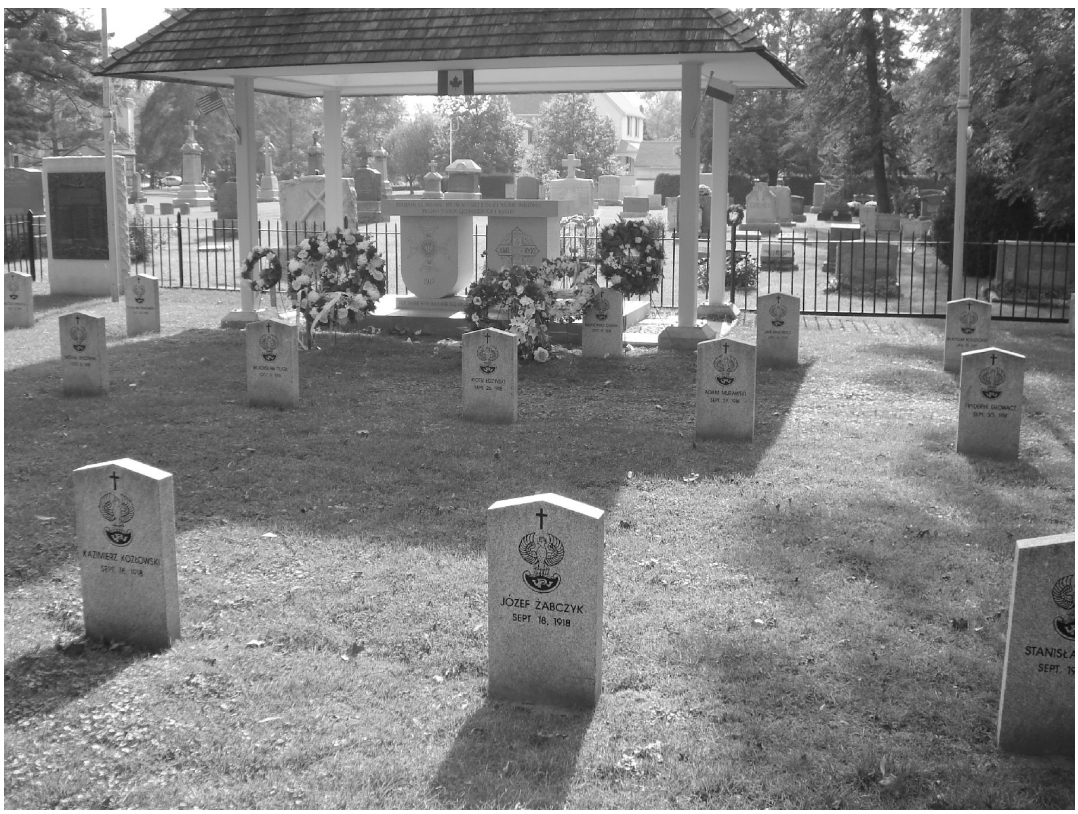

Fig. 5. Cemetery in Niagara-on-the-Lake, the burial place of Polish soldiers who died of the Spanish flu in autumn 1918; http://pl.wikipedia.org/w/ index.php?title=Plik:Niagara-on-the-Lake_Polish_Military_Cemetery_2.jpg (access: 31 May 2012).

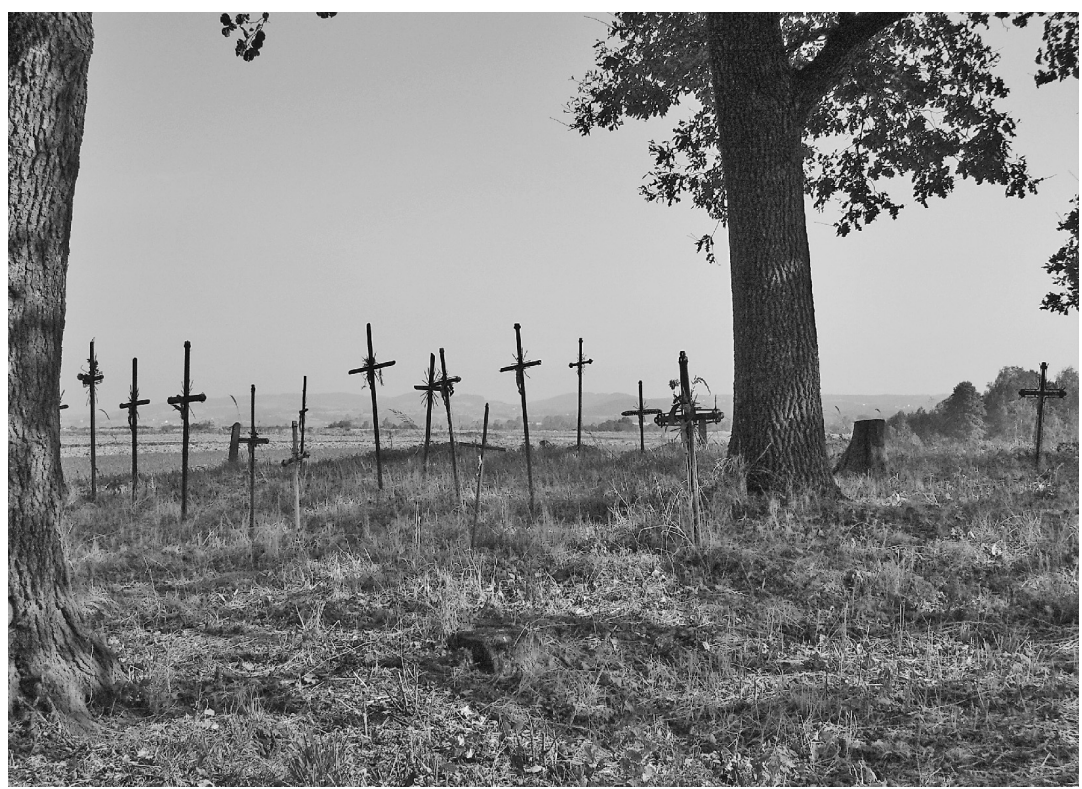

Fig. 6. Cemetery of Spanish flu victims in Chocznia near Wadowice; photograph by Szymon Słomczyński 
trained there, died. They did not live long enough to be transferred to Europe, so instead of fighting for their lives in the trenches, they died of one of the most effective killers of all times, the Spanish flu virus. Twenty five of them are buried in a common grave, renovated in 2000 by the Polish community in Canada.

Another cemetery with Spanish flu victims is located near Kraków, in a place called Boża Męka (Divine Suffering), alongside the old, disused Sobieski's route running between Chocznia and Wadowice. The row of crosses surrounded by a beech grove is located near a bend in a dirt road; the local inhabitants never seem to visit the place. The cemetery is one of the very few examples of an old custom whereby people dying in an epidemic had to be buried outside the town or village boundaries. When visiting the cemetery you wonder about the deadliness of the Spanish flu pandemic, and above all the victims, often very young people, who died unexpectedly from an illness which is usually just a passing, seasonal disruption.

\section{Szymon Słomczyński}

"There are sick people everywhere - in cities, towns and villages" The course of the Spanish flu epidemic in Poland

(Summary)

The 1918-20 epidemic of Spanish flu killed 50 to 100 million people throughout the world. As observed during its course, as well as later research, the pandemic came in waves and in several stages. The most lethal was the wave which struck in the autumn of 1918, coinciding with the end of World War I. The pandemic was concurrent with several changes of fundamental importance for both Europe and the world's political, social and cultural history, which undoubtedly had an impact on the fact that one of the most severe pandemics in the history of mankind is often called "the forgotten epidemic". In recent years, however, the Spanish flu pandemic has become the subject of multiple analyses, in the fields of both natural and social sciences.

Until now, little was known about the course of the epidemic in Poland. This article is an attempt to fill the gap - at least to some extent. The source data collected has made it possible to more or less accurately determine exactly when the epidemic raged through Poland. Similarly to the neighbouring countries, the epidemic began in the summer and peaked in the autumn of 1918 with the last registered instances of Spanish flu being noted in the winter of 1920. By confronting the knowledge gleaned from Western literature on the subject with the results of research conducted by Russian scientists (which seem to be unknown in the West) as well as my own findings, it was possible 
to ascertain the course of the epidemic in Poland in a pan-European context. As demonstrated by the example of Jastrzębia, a village in the Tarnów district, Spanish flu may have had a significant impact on the annual mortality rate. It also disrupted, at least temporarily, the normal course of social life. This article is a contribution to further research on this topic.

Szymon Słomczyński - Institute of History, Jagiellonian University; e-mail: szymon.slomczynski@gmail.com 